\title{
Editorial corner
}

\section{The Polypropylene Pope would be 70}

\author{
T. Bárány ${ }^{*}$ \\ Department of Polymer Engineering, Faculty of Mechanical Engineering, Budapest University of Technology and \\ Economics, Müegyetem rkp. 3., H-1111, Budapest, Hungary
}

It is the second issue dedicated to the $70^{\text {th }}$ birthday of the first editor-in-chief of Express Polymer Letters, Professor József Karger-Kocsis, who passed away in December 2018.

His diverse scientific research covered thermoplastics, thermosets, and rubbers, but polypropylene (PP) was present in entire his professional career. He published the first PP-related papers in the 1970s, and throughout his life, he wrote more than a hundred papers. In 1995, he edited a book series of three volumes: 'Polypropylene: Structure, Blends and Composites', in which the academic knowledge of this field was collected. After the success of this series, he edited a cyclopedia about PP: 'Polypropylene: An A-Z Reference' (1999). Almost 20 years later, he decided to edit a new handbook on PP. It was a great honor for me to take part in this work. It took a year, and we made the finishing touches at

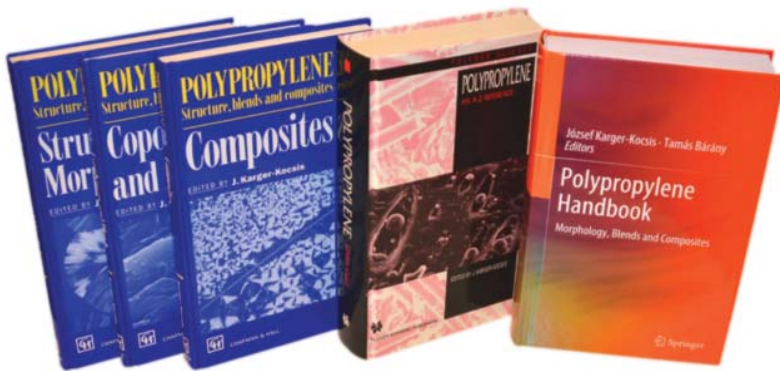

Handbooks on polypropylene edited by Prof. Karger-Kocsis the benefits of these modifications? - these aspects were characteristic of his scientific thinking...

In this second issue, with seven articles, in which his students and ex-colleagues present their newest research results, which were also inspired and helped by professor Karger-Kocsis: the first paper is prepared by his Greek PhD student (Dr. N. M. Barkoula et al.) about the degradation of different resins, the next paper is a review on smart polymer nanocomposites by his Malaysian friends (Prof. Z. A. M. Ishak and Prof. W. S. Chow). The next article, prepared by his friend from New-Zealand (Prof. S. Fakirov), deals with the evergreen question of polymer nanocompos- his deathbed, but unfor-

tunately, he did not live to see the publication of the 'Polypropylene Handbook: Morphology, Blends and Composites' (Springer Nature, Cham, https://doi.org/ 10.1007/978-3-030-12903-3). All the chapters were prepared by well-known experts, and they summarize existing and established knowledge and rules, as well as the latest research results. The book focuses on processing-structure-property relationships: how to influence them, what can be achieved, and what are ites; and there is a comparative study by his Greek friend (Prof. G. C. Psarras et al.) on the electrical properties of different forms of carbon allotropes - epoxy nanocomposites. The next paper is prepared by his first $\mathrm{PhD}$ student (Prof. C-M. Wu et al. from Taiwan) about cellulose nanocomposites. There is an article by his Austrian friend (Dr. M. Gahleitner et al.) on the $\beta$-nucleation of isotactic polypropylene. Finally, there is a paper on the impact characterization of polymer foams prepared by four generations of his close Hungarian colleagues: Prof. T. Czigány was his PhD student, Dr. T. Bárány was supervised by Prof. Czigány, Dr. Bárány supervised Dr. Á. Kmetty and M. Tomin is a PhD student of Dr. Kmetty. 